\title{
ECONOMIC GROWTH MODEL LOCATION QUOTIENT (LQ) IN EAST JAVA PROVINCE
}

\author{
Wiwin Priana ${ }^{1}$ \\ 1.Universitas Pembangunan Nasional "Veteran” Jawa Timur \\ email: wiwinp@yahoo.com
}

\begin{abstract}
Sectors of the economy of a region is the motor of national development because without the support of the regions are then national development will be difficult to achieve. Similarly, the motto promoted by the national development, regional development was also of, by, and for the region. So regional development is the fruit of a combination of innovation and the area itself to the achievement of progress and prosperity.

One indicator of the achievement of a regional development is economic growth continues to increase towards significantly. This means that economic growth can continue to increase along with improvements exist in the driving sectors of the economy. The success of regional development are also assessed on the ability of the area to meet community needs and develop all the existing potential. This study is a continuation of the first research on the growth sectors of shift share in regencies and municipalities in East Java, it can be seen the results of Shift Share PR (Potential Regional) of counties and cities that have the advantages that drive sector GDP growth in East Java. PR <dQ means the sector in the district to encourage economic growth in East Java. Of PR (Potesi Regional), then in this study will be Location Qoutien. For the GDP when LQ> 1 then the sector is a sector basis and when LQ $<1$ sectors are the sectors non bases.
\end{abstract}

Keywords: Base Sector, Sector Non Base

JEL Classification: R12, O41

\section{PENDAHULUAN}

Pembangunan merupakan proses perubahan yang dilaksanakan oleh semua bangsa- bangsa yang ada di dunia karena pem-bangunan merupakan suatu bagian yang tak terpisahkan dari usaha untuk mencapai kema-juan bagi bangsa itu sendiri. Sedangkan pembangunan nasional merupakan rangkaian upaya pembangunan yang dilakukan secara terus menerus dan meliputi seluruh aspek kehidupan masyarakat, bangsa, dan negara. Tujuan utama dari suatu pembangunan nasional adalah untuk mewujudkan masya-rakat adil dan makmur yang merata berda-sarkan Pancasila dan Undang-Undang Dasar 1945. Pembangunan nasional dilaksanakan bersama oleh seluruh komponen, yakni masyarakat dan pemerintahan. Masyarakat adalah pelaku utama sebagai motor dalam pembangunan tersebut, sedangkan pemerintah adalah sebagai pengarah atau pengontrol yang nantinya dapat menciptakan suasana yang menunjang satu sama lain.

Unsur utama pembangunan terletak pada usaha melakukan kombinasi baru dalam kegiatan perekonomian yang di dalamnya terkandung berbagai kemungkinan yang ada dalam keadaan yang berkembang dan man-tap. Kombinasi baru ini muncul dalam bentuk apa yang disebut sebagai inovasi (Anonim, 2000).

Pembangunan nasional adalah dari, oleh, dan untuk rakyat yang dilaksanakan di semua aspek kehidupan dan diarahkan untuk mencapai kemajuan dan kesejahteraan. Pembangunan dilakukan secara berencana, me- 
nyeluruh, terarah, terpadu, dan berkelanjutan dalam rangka peningkatan taraf hidup masya-rakat. Pembangunan nasional menitikberat-kan pada bidang ekonomi yang merupakan motor penggerak utama pembangunan dan didorong dengan pembangunan bidang lain yang dilaksanakan secara serasi dan terpadu. Jadi pada dasarnya, pembangunan ekonomi menurut Aditya (2010) adalah:

1. Usaha untuk meningkatkan pendapatan perkapita masyarakat, dimana tingkat pertumbuhan Gross Domestic Product (GDP) melebihi tingkat pertambahan pen-duduk pada suatu tahun.

2. Usaha untuk melakukan perombakan dan modernisasi dalam struktur perekonomian yang umumnya masih bersifat tradisional.

Salah satu indikasi dari pembangunan adalah terjadinya pertumbuhan ekonomi (economic growth) yang ditunjukkan oleh pertambahan produksi atau pendapatan nasional. Keberhasilan pembangunan akan dapat mempertinggi kemampuan bangsa dalam perubahan di bidang lainnya. Salah satu tujuan pembangunan jangka panjang bidang pertumbuhan ekonomi adalah terciptanya stabilitas ekonomi di bidang pertanian dan industri (Aditya, 2010).

Pembangunan daerah merupakan subsistem dari pembangunan nasional dan merupakan bagian yang tidak dapat dipisahkan dari pembangunan nasional. Oleh karena itu pembangunan daerah dilaksanakan pada berbagai aspek kehidupan, yang antara lain diupayakan dengan melaksanakan pembangunan di bidang ekonomi (BPS Provinsi Jawa Timur, 2006).Sehubungan dengan keinginan untuk mewujudkan pembangunan seperti apa yang diharapkan, ada dua kondisi yang perlu diperhatikan karena dapat berpengaruh terhadap proses perencanaan pembangunan daerah, yaitu: (1) tekanan yang berasal dari lingkungan dalam negeri maupun luar negeri yang mempengaruhi kebutuhan daerah dalam proses pembangunan pereko-nomiannya; (2) kenyataan bahwa perekonomian daerah dalam suatu negara di-pengaruhi oleh setiap sektor secara berbeda-beda, misalkan beberapa daerah mengalami pertumbuhan pada sektor industrinya se-dangkan daerah lain mengalami penurunan. Inilah yang menjelaskan perbedaan pers-pektif masyarakat daerah mengenai arah dan makna pembangunan daerah (Kuncoro, 2005).

Secara umum dapat dikatakan bahwa regionalisasi kegiatan ekonomi berhubungan erat dengan pola perkembangan, jenis ekonomi, dan perubahan peranan berbagai kegiatan ekonomi itu dalam keseluruhan kegiatan ekonomi. Berkaitan hal tersebut, maka analisis perkembangan pembangunan suatu daerah semakin kecil suatu wilayah akan semakin mudah dalam mengidentifikasi ber-bagai permasalahan dan sumber-sumber potensialnya sehingga akan memudahkan dalam penyusunan rencana secara kom-prehensif (multisektoral) dan semakin mudah untuk menetapkan sasaran-sasaran yang i-ngin dicapai.

Ada sembilan sektor ekonomi atau kelompok lapangan usaha yang umumnya dapat dihitung dalam PDB atau PDRB jika dalam lingkup regional/daerah (BPS Provinsi Jawa Timur, 2010), yaitu:

1. Sektor pertanian

2. Sektor pertambangan dan penggalian

3. Sektor industri pengolahan

4. Sektor listrik, gas dan air bersih

5. Sektor bangunan

6. Sektor perdagangan, hotel dan restoran

7. Sektor pengangkutan dan komunikasi

8. Sektor keuangan, persewaan dan jasa perusahaan

9. Sektor jasa-jasa

Dari perhitungan sektor-sektor ekonomi tersebut, kondisi struktur ekonomi dari suatu daerah atau negara dapat ditentukan. 
Suatu daerah dikatakan agraris bila peran sektor pertanian sangat dominan dalam PDRB-nya, demikian pula sebaliknya, dikatakan sebagai daerah industri apabila yang lebih dominan adalah sektor industrinya. Provinsi Jawa Timur adalah kontributor terbesar dalam PDRB setelah Jawa Barat karena letak sumber-sumber ekonomi senantiasa dipisah-kan oleh spasial atau ruang maka perkem-bangan ekonomi suatu daerah senantiasa berbeda dengan daerah lainnya. Demikian ju-ga halnya dengan permasalahan perwila-yahan pembangunan di Provinsi Jawa Timur (Anonim, 2010:1).

\section{KAJIAN PUSTAKA DAN HIPOTE- SIS}

\section{Produk Domestik Regional Bruto (PD-} RB)

Menurut Badan Pusat Statistik Provinsi Jawa Timur, Produk Domestik Regional Bruto dapat didefinisikan sebagai berikut:

1. Ditinjau dari segi produksi, merupakan jumlah nilai produk akhir atau nilai tambah dari barang dan jasa yang dihasilkan oleh unit-unit produksi yang dimiliki oleh penduduk suatu wilayah.

2. Ditinjau dari segi pendapatan, merupakan jumlah pendapatan atau balas jasa yang diterima oleh faktor produksi yang dimiliki oleh penduduk wilayah itu yang ikut serta dalam proses produksi dalam jangka waktu tertentu.

3. Ditinjau dari segi pengeluaran, merupakan pengeluaran konsumsi rumah tangga dan lembaga swasta yang tidak mencari untung, konsumsi pemerintah, dan pembentukan modal tetap perubahan stock dan ekspor netto (BPS Jawa Timur, 2006).
Definisi-definisi yang berhubungan dengan Produk Domestik Regional Bruto menurut beberapa pendapat, di antaranya: 1. Produk Domestik Regional Bruto adalah total nilai produksi barang dan jasa yang diproduksikan di suatu daerah tertentu dalam waktu tertentu biasanya dalam 1 tahun. Oleh karena itu maka produk domestik regional bruto menunjukan kemampuan suatu daerah ter-tentu dalam menghasilkan pendapatan atau jasa kepada faktorfaktor yang ikut berperan serta dalam proses produksi di daerah setempat. Pertumbuhan ekono-mi dalam negeri yang tercermin dalam produk domestik regional bruto sangat besar pengaruhnya terhadap besar ke-cilnya konsumsi masyarakat. (Kunco-ro, 2006:27)

2. Produk Domestik Bruto (GDP-Gross Domestic Products) adalah nilai total atas segenap output akhir yang dihasilkan oleh suatu perekonomian (baik yang dilakukan oleh penduduk warga negara maupun orang-orang dari negara lain yang bermukim di negara tersebut) (Todaro dan Smith, 2004).

3. Pengertian Produk Domestik Regional Bruto menurut Badan Pusat Statistik adalah nilai produksi barang dan jasa yang diproduksi di suatu wilayah (regional) tertentu dalam waktu tertentu dalam satu tahun (Anonim, 2002).

Pertumbuhan ekonomi bisa bersumber dari pertumbuhan pada sisi AD (Aggregate Demand) atau AS (Aggregate Supply). Titik potong antara kurva AD dengan AS adalah titik keseimbangan ekonomi (equilibrium) yang menghasilkan suatu jumlah output agregat (Produk Domestik Bruto) tertentu dengan tingkat harga umum tertentu. 


\section{METODE PENELITIAN} Analisis LQ (Location Quotien)

Dalam analisis ini digunakan beberapa data dari Produk Domestik Regional Bruto (PDRB) Provinsi Jawa Timur dan PDRB per sektor kabupaten atau kota serta tenaga kerja per sektor.

1. PDRB daerah yang menjadi acuan

Adalah rata-rata total nilai produksi barang dan jasa yang diproduksi di suatu wilayah (regional) tertentu dan dalam waktu tertentu (dalam waktu satu tahun) daerah yang menjadi acuan. Dalam hal ini adalah Provinsi Jawa Timur dan dinya-takan dalam satuan jutaan rupiah.

2. Tenaga kerja

Adalah orang yang telah bekerja di berbagai sektor dalam suatu wilayah dalam satuan orang.

\section{Jenis dan Sumber Data}

Data yang digunakan dalam penelitian ini adalah data sekunder berupa data time series yang diambil dari tahun 2010 sampai dengan tahun 2014. Sumber data diperoleh dari kantor Badan Pusat Statistik Propinsi Jawa Timur dan perpustakaan-perpustakaan lain baik itu milik lembaga pendidikan maupun pemerintah daerah Jawa Timur.

\section{Teknik Pengumpulan Data}

Dalam penelitian ini teknik pengumpulan data dilakukan dengan dua cara, yaitu

1. Studi Kepustakaan

Adalah pengumpulan data yang dilakukan dengan membaca buku-buku literatur sebagai bahan pustaka yang dapat menunjang masukan yang dibahas dalam skripsi ini.

2. Studi Lapangan

Penelitian lapangan ini dimaksudkan untuk mendapatkan datadata sekunder yang diperlukan untuk penulisan skripsi, data-data laporan, catatan-catatan yang berhubungan dengan masalah yang dibahas pada lembagalembaga yang telah disebutkan diatas.

\section{Teknik Analisis Pengolahan Data}

Data yang berhubungan dengan obyek penelitian disusun untuk selanjutnya diolah dengan menggunakan alat analisis matematis yakni berupa Analisis Location Quotien / LQ untuk kemudian dilakukan pengamatan selama kurun waktu tertentu. Notasi yang digunakan dalam kedua teknik analisis dari penelitian ini adalah :

1. Analisis LQ ( Location Quotient)

PDRB atau Tenaga Kerja persektor kabupaten/kota

PDRB atau Tenaga Kerja persektor Jawa Timur

LQ

Jumlah PDRB atau Tenaga Kerja kabupaten/kota

Jumlah PDRB atau Tenaga kerja Jawa Timur

LQ $<1$ adalah sektor non basis LQ $>1$ adalah sektor basis

\section{ANALISIS DATA DAN PEMBAHA-} SAN

Dari PDRB kota dan daerah di propinsi Jawa Timur dihitung dengan Rumus Loca-tion Quotien maka ditemukan sektor basis dari masing-masing daerah. Seperti tabel berikut ini :

1. Sektor Pertanian

Tabel : 1 Sektor Basis sektor pertanian

kabupaten/kota di Jawa Timur

\begin{tabular}{|l|l|l|}
\hline & $\begin{array}{l}\text { Nilai LQ Sektor } \\
\text { Pertanian }\end{array}$ & $\begin{array}{l}\text { Kabupaten /Kota di jawa } \\
\text { Timur }\end{array}$ \\
\hline 1 & 1,29 & Kabupaten Mojokerto \\
\hline 2 & 2,67 & Kabupaten Lamongan \\
\hline 3 & 1,33 & Kabupaten Bojonegoro \\
\hline 4 & 1,58 & Kabupaten Tuban \\
\hline 5 & 1.90 & Kabupaten Probolinggo \\
\hline 6 & 1,66 & Kabupaten Pasuruan \\
\hline
\end{tabular}




\begin{tabular}{|c|c|c|}
\hline 7 & 1,87 & Kaabupaten Bangkalan \\
\hline 8 & 2,69 & Kabuapaten Sampang \\
\hline 9 & 3,18 & Kabupaten Pamekasan \\
\hline 10 & 3,10 & Kabupaten Sumenep \\
\hline 11 & 2,39 & Kabupaten Madiun \\
\hline 12 & 2,36 & Kabupaten Ponorogo \\
\hline 13 & 2,05 & Kabupaten Magetan \\
\hline 14 & 2,42 & Kabupaten Ngawi \\
\hline 15 & 2,46 & Kabupaten Pacitan \\
\hline 16 & 1,78 & Kabupaten Kediri \\
\hline 17 & 2,52 & Kabupaten Trenggalek \\
\hline 18 & 1,06 & Kabupaten Tulungagung \\
\hline 19 & 1,82 & Kabupaten Jombang \\
\hline 20 & 1,83 & Kabupaten Nganjuk \\
\hline 21 & 2,89 & Kabupaten Banyuwangi \\
\hline 22 & 2,28 & Kabupaten Jember \\
\hline 23 & 1,87 & Kabupaten Situbondo \\
\hline 24 & 2,80 & Kabupaten Bondowoso \\
\hline 25 & 1,65 & Kabupaten Malang \\
\hline 26 & 2,86 & Kabupaten Blitar \\
\hline 27 & 1,25 & Kota Batu \\
\hline & & \\
\hline
\end{tabular}

\begin{tabular}{|c|c|c|}
\hline & $\begin{array}{l}\text { Nilai LQ Sektor } \\
\text { Pertambangan }\end{array}$ & $\begin{array}{l}\text { Kabupaten /Kota di } \\
\text { jawa Timur }\end{array}$ \\
\hline 1 & 1,90 & Kabupaten Gresik \\
\hline 2 & 19,68 & $\begin{array}{l}\text { Kabupatem } \\
\text { Bojonegoro }\end{array}$ \\
\hline 3 & 8,08 & Kabupaten Tuban \\
\hline 4 & 4,51 & Kabupaten Sampang \\
\hline 5 & 4,71 & Kabupaten Sumenep \\
\hline 6 & 1,57 & Kabupaten Pacitan \\
\hline 7 & 1,06 & Kabupaten Kediri \\
\hline 8 & 1,10 & $\begin{array}{l}\text { Kabupaten } \\
\text { Tulungagung }\end{array}$ \\
\hline 9 & 2,15 & $\begin{array}{l}\text { Kabupaten } \\
\text { Banyuwangi }\end{array}$ \\
\hline 10 & 1,32 & Kabupaten Jember \\
\hline 11 & 1,03 & Kabupaten Situbondo \\
\hline 12 & 1,26 & Kabupaten Biltar \\
\hline
\end{tabular}

Ada 12 daerah di Jawa Timur yang merupakan Basis Pertambangan artinya pertambangan ini ada $12 / 38 \times 100 \%=34,21 \%$ 3.Sektor Industri

Tabel : 3 Sektor Basis sektor Industri Pengolahan Kabupaten/kota di Jawa Timur

\begin{tabular}{|l|l|l|}
\hline & $\begin{array}{l}\text { Nilai LQ Sektor } \\
\text { Industri } \\
\text { Pengolahan }\end{array}$ & $\begin{array}{l}\text { Kabupaten /Kota di } \\
\text { jawa Timur }\end{array}$ \\
\hline 1 & 1,71 & Kabupaten Sidoarjo \\
\hline 2 & 1,86 & Kabupaten Gresik \\
\hline 3 & 1,22 & Kabupaten Pasuruan \\
\hline 4 & 2,67 & Kota Malang \\
\hline 5 & 1,19 & \\
\hline
\end{tabular}


Sektor industri yang menjadi sek-tor basis di daerah kabupaten /kota di Jawa Timur ternyata hanya 5 daerah atau 13,15 $\%$.

4 Sektor, Listrik , Gas , Air.

Tabel : 4 Sektor Basis sektor Listrik, Gas, Air Kabupaten/kota di Jawa Timur

\begin{tabular}{|l|l|l|}
\hline & $\begin{array}{l}\text { Nilai LQ Sektor } \\
\text { Listri, Gas, Air }\end{array}$ & $\begin{array}{l}\text { Kabupaten /Kota di jawa } \\
\text { Timur }\end{array}$ \\
\hline 1 & 1,07 & Kabupaten Sidoarjo \\
\hline 2 & 1,23 & Kabupaten Gresik \\
\hline 3 & 2,60 & Kabupaten Tuban \\
\hline 4 & 1,67 & Kota Mojokerto \\
\hline 5 & 2,20 & Kota Pasuruan \\
\hline 6 & 1,54 & Kabupaten Pasuruan \\
\hline 7 & 1,69 & \\
\hline
\end{tabular}

Ternyata hanya 7 daerah yang mempunyai sektor basis pada sektor Listrik, Air, Gas yaitu 7/38 x 100\%= $18,42 \%$

5 Sektor Konstruksi/Bangunan

Tabel : 5 Sektor Basis sektor Konstruksi

Kabupaten/kota di Jawa Timur

\begin{tabular}{|l|l|l|}
\hline & $\begin{array}{l}\text { Nilai LQ Sektor } \\
\text { Konstruksi }\end{array}$ & $\begin{array}{l}\text { Kabupaten /Kota di jawa } \\
\text { Timur }\end{array}$ \\
\hline 1 & 1,47 & Kota Surabaya \\
\hline 2 & 1,25 & Kota Pasurua \\
\hline 3 & 2,06 & Kabupaten Bangkalan \\
\hline 4 & 1,13 & Kabupaten Pamekasan \\
\hline 5 & 1,20 & Kota Madiun \\
\hline 6 & 1,50 & Kabupaten Magetan \\
\hline 7 & 1,17 & Kabupaten Pacitan \\
\hline 8 & 2,06 & \\
\hline
\end{tabular}

Sektor konstruksi dan bangunan yang menjadi sektor basis di daerah kabupaten /kota di Jawa Timur ternyata 8 daerah atau $21,05 \%$.

6.Sektor Perdagangan, Hotel

Tabel : 6 . Sektor Basis sektor

Perdagangan, Hotel Kabupaten/kota di Jawa Timur

\begin{tabular}{|c|c|c|}
\hline & $\begin{array}{l}\text { Nilai LQ Sektor } \\
\text { Perdagangan dan } \\
\text { Hotel }\end{array}$ & $\begin{array}{l}\text { Kabupaten /Kota di } \\
\text { jawa Timur }\end{array}$ \\
\hline 1 & 1,14 & Kabupaten Lamongan \\
\hline 2 & 1.31 & Kota Mojokerto \\
\hline 3 & 1.72 & Kota Surabaya \\
\hline 4 & 1,45 & Kota Probolinggo \\
\hline 5 & 1,25 & Kota Pasuruan \\
\hline 6 & 1,13 & Kabupaten Madiun \\
\hline 7 & 1,37 & Kota Madiun \\
\hline 8 & 1,23 & $\begin{array}{l}\text { Kabupaten Tulung } \\
\text { Agung }\end{array}$ \\
\hline 9 & 1,22 & Kabupatem Jombang \\
\hline 10 & 1,23 & Kabupaten Nganjuk \\
\hline 11 & 1,20 & Kabupaten Situbondo \\
\hline 12 & 1,26 & Kota Malang \\
\hline 13 & 1,83 & Kota Blitar \\
\hline 14 & 1,59 & Kota Batu \\
\hline
\end{tabular}

Pada sektor Perdagangan, Hotel ada 14 daerah yang basis atau $14 / 38 \times 100 \%=$ $36,84 \%$

7. Sektor Pengangkutan dan Komunikasi Tabel : 7 Sektor Basis sektor Pengankutan Kabupaten/kota di Jawa Timur

Nilai LQ Sektor 


\begin{tabular}{|l|l|l|}
\hline & Pengangkutan & Timur \\
\hline 1 & 2.08 & Kabupaten Sidosrjo \\
\hline 2 & 2,35 & Kota Mojokerto \\
\hline 3 & 1,72 & Kota Surabaya \\
\hline 4 & 2,28 & Kota Probolinggo \\
\hline 5 & 1,03 & Kabupaten Probolinggo \\
\hline 6 & 2,09 & Kota Pasuruan \\
\hline 7 & 1,18 & Kota Madiun \\
\hline 8 & 1,37 & Kabupaten Pacitan \\
\hline 9 & 1,06 & Kabupaten Tulungagung \\
\hline 10 & 1,23 & Kota Blitar \\
\hline 11 & 1,83 & \\
\hline
\end{tabular}

\begin{tabular}{|l|l|l|}
\hline 10 & 1,07 & Kabupaten Jember \\
\hline 11 & 1,59 & Kota Malang \\
\hline 12 & 2,49 & Kota Blitar \\
\hline & & \\
\hline
\end{tabular}

\section{Pada sektor Keuangan, persewaan} yang basis sebanyak 12 daerah atau $31,57 \%$.

9. Sektor Jasa-Jasa

Tabel : 9 Sektor Basis sektor Jasa- Jasa

Kabupaten/kota di Jawa Timur

\begin{tabular}{|c|c|c|}
\hline & $\begin{array}{l}\text { Nilai LQ Sektor } \\
\text { Jasa }\end{array}$ & $\begin{array}{l}\text { Kabupaten /Kota di jawa } \\
\text { Timur }\end{array}$ \\
\hline 1 & 1,09 & Kabupaten Mojokerto \\
\hline 2 & 1,24 & Kabupaten Lamongan \\
\hline 3 & 1,07 & Kabupaten Bojonegoro \\
\hline 4 & 2,40 & Kota Mojokerto \\
\hline 5 & 1,60 & Kota Probolinggo \\
\hline 6 & 1,45 & Kota Pasuruan \\
\hline 7 & 1,25 & Kabupaten Pasuruan \\
\hline 8 & 2,14 & Kabupaten Bangkalan \\
\hline 9 & 1,62 & Kabupaten Sampang \\
\hline 10 & 1,71 & Kabupaten Pamekasan \\
\hline 11 & 1,24 & Kabapaten Sumenep \\
\hline 12 & 1.91 & Kabupaten Madiun \\
\hline 13 & 1,88 & Kota Madiun \\
\hline 14 & 1,27 & Kabupaten Ponorogo \\
\hline 15 & 2,52 & K abupaten Magetan \\
\hline 16 & 1.70 & Kabupaten Ngawi \\
\hline 17 & 2,29 & Kabupaten Pacitan \\
\hline 18 & 2,03 & Kabupaten Kediri \\
\hline
\end{tabular}




\begin{tabular}{|l|l|l|}
\hline 19 & 1.96 & Kabupaten Trenggalek \\
\hline 20 & 1,52 & Kabupaten Trenggalek \\
\hline 21 & 1,34 & Kabupaten Jombang \\
\hline 22 & 2,33 & Kabupaten Nganjuk \\
\hline 23 & 1,50 & Kabupaten Malang \\
\hline 24 & 1,64 & Kabupaten Blitar \\
\hline 25 & 1,49 & Kota Blitar \\
\hline 26 & 2,64 & Kota Batu \\
\hline 27 & 2,08 & \\
\hline
\end{tabular}

Sektor Jasa-Jasa ada 27 kabupaten/Kota yang merupakan sektor basis atau $71,05 \%$.

\section{ANALISIS DATA DAN PEMBAHA- SAN}

Sektor Pertanian merupakan sektor basis kabupaten/kota di Jawa Timur, bahwa sektor basis kabupaten/kota di Jawa Timur adalah sektor Pertanian dan sektor jasa-jasa lain maka bisa disimpulkan bahwa sebagian besar daerah di Jawa Timur ini masih sektor tradisional yaitu sektor pertanian atau dapat dikatakan bahwa sebagian besar masih sector pedesaan untuk itu maka pemerintah Jawa Timur dan pemerintah daerah kabupaten memperhatikan kehidupan masyarakatnya yang masih pedesaan kemajuan ekonomi hanya di beberapa daerah perkotaan dan sektor ini masih sedikit daerahnya yang itu tidak lebih dari $20 \%$ daerah, biasanya daerah yang berdekatakan dengan kota Surabaya seperti Gresik, Sidoarjo, Pasuruan Mojo-kerto. Tetapi daerah yang jauh dari kota Surabaya mengandalkan sektor ekonomi Pertanian.

Sektor jasa-jasa lain adalah implementasi dari usaha kecil dan menengah sek-tor ini ternyata juga berada di daerah pede-saan artinya daerah yang masih mengan-dalkan sektor pertanian untuk itu pemerintah daerah Provinsi dan kabupaten hendaknya dapat meningkatkan kehidupan masarakat di sektor ini.

Sektor Industri dan perdagangan berada di daerah pusat pertumbuhan, dan sector pertanian berada di daerah yang jauh dari pu-sat pertumbuhan, untuk itu perlu adanya re-gulasi dan prioritas pembangunan untuk dae-rah perdesaan karena dalam penelitian ini ter-nyata sector basis berada di daerah perdesaan dan jauh dari kota Surabaya sebagai pusat pertumbuhan di Jawa Timur bahkan di Indo-nesia bagian timur.

\section{KESIMPULAN, IMPLIKASI, SARAN, DAN BATASAN}

Dari hasil penelitian tersebut diatas maka dapat disiumpulkan bahwa daerah yang mempunyai sektor basis terbanyak ada-lah sektor pertanian 27 daerah atau $71,05 \%$ dan sector Jasa jasa sebanyak 27 Daerah $(71,05 \%)$. Sektor yang paling sedikit adalah sektor Industri 5 daerah atau 13,15 $\%$ dan Sektor Listri, Gas, Air sebanyak 7 daerah atau 18,14\%.

Pemerintah diharapkan mendorong sektor yang kecil nilai basisnya seperti sector industri, dan Listrik, ini artinya infrastruktur belum merata, perlu adanya pengeluaran pemerintah untuk mendorong sektor tersebut agar pembangunan menjadi merata di seluruh provinsi Jawa Timur

\section{DAFTAR PUSTAKA}

Adisasmita, Raharjo, 2010. Pembangunan Kawasan dan Tata Ruang, Graha Pustaka, Yogyakarta

Aditya, Agung, 2010,Analisis Ekonomi Regional Pada Satuan Wilayah Pembangunan (SWP ) II Provinsi JAWA TIMUR (Kab. Sampang, Kab. Pamekasan, dan Kab. Sumenep), Skripsi Fakultas Ekonomi Universitas Pembangunan Nasional "Veteran" Jawa Timur, Surabaya 
Anonim, .Produk Domestik Regional Bruto Daerah Tingkat I Jawa Timur 2009

Pergeseran Tahun Dasar dan Estimasi Produk Domestik Regional Bruto Daerah Tingkat I Jawa Timur Tahun 2013, Badan Pusat Statistik Daerah Tingkat I Jawa Timur, Surabaya

Anwar, M. Arsyad, 1999. Pemikiran, Pelaksanaan, dan Perintisan Pembangunan Ekonomi. Gramedia, Jakarta

Arsyad, Lincolin, 1999. Pengantar Perencanaan dan Pembangunan Ekonomi Daerah, Edisi pertama, BPFE, Jogjakarta

Bayu, Septian, 2009. Analisis Ekonomi Regional Pada Satuan Wilayah Pembangunan (SWP) IX Propinsi Jawa Timur (Kab. Bojonegoro dan Kab. Tuban), Skripsi Fakultas Ekonomi Universitas Pembangunan Nasional "Veteran" Jawa Timur

Chumaidy, Yanuar, 2006. Analisis Potensi Sektoral dalam Pengembangan Satuan Wilayah Pembangunan VI Tahun 19962003, Skripsi Fakultas Ekonomi Universitas Airlangga, Surabaya

Fembyantara, Fhenda, 2009. Analisis Tipologi Daerah pada Satuan Wilayah Pembangunan I Gerbangkertasusila Jawa Timur, Skripsi Fakultas Ekonomi Universitas Pembangunan Nasional "Veteran" Jawa Timur, Surabaya

Herwindo, Bagus, 2000. Analisis Ekonomi Regional Terhadap Perkembangan Ekonomi di Satuan Wilayah Pembangunan VII Jawa Timur 1993-1998), Skripsi Fakultas Ekonomi Universitas Airlangga , 2004. PDRB Kabupaten / Kota se - Jawa Timur Periode 2009, BPS Provinsi Jawa Timur Surabaya , 2009. ProdukDomestik Regional Bruto Kabupaten / Kota Se Jawa Timur 2004-2008, Badan Pusat Statistik Provinsi Jawa Timur dan Badan Perencanaan Pembangunan Daerah Provinsi Jawa Timur , 2009. Produk Domestik Regional Bruto Provinsi Jawa Timur, Badan Pusat Statistik Provinsi Jawa Timur dan Badan Perencanaan Pembangunan Daerah Provinsi Jawa Timur 2006. Analisis Potensi

Daerah, dikutip dari Modul Pelatihan District and Provincial Economic Development, Yogyakarta 